perfusion, who responded to a low protein diet and had a good prognosis, and those with fixed filtration and perfusion resistant to dietary interventions, whose disease progressed relentlessly.

In conclusion, we believe that although a low protein diet is beneficial in slowing the progression of chronic renal failure, such a dietary effect depends on the underlying nephropathy and the nature of the glomerular perfusion pattern. Patients with increased or reversible glomerular perfusion are likely to be the ones with mild focal glomerular involvement. They are the most likely to benefit from dietary treatment. Patients with severe vascular and diffuse glomerular disease, as well as fixed renal perfusion, are unlikely to improve with such a diet. In the future the therapeutic approach to patients with chronic renal disease might have to be tailored to the underlying nephropathy once its haemodynamic profile has been established. Meanwhile, early introduction of dietary protein restriction should be seriously considered in patients with chronic renal failure.

\section{References}

1 Mitch WE, Walser M, Buffington CA, Lemann J. A simple method for estimating progression of chronic renal failure. Lancet 1976; ;i:1326-8.

Rutherford WE, Blondin J, Miller JP, et al. Chronic progressive renal disease rate of change of serum creatinine circulation. Kidney Int 1977;11:62-70.

Brenner BM, Meyer TW, Hostetter TH. Dietary protein intake and the proin the pathogenesis of progressive glomerular sclerosis in ageing, renal ablation and intrinsic renal disease. $N$ Engl f Med 1982;307:652-9.

4 Olson JC, Hostetter TH, Rennke HG, Brenner BM, Venkatachalam MA Altered glomerular permeselectivity and progressive sclerosis following extreme ablation of renal mass. Kidney Int 1982;22:112-26.

5 Allison MEM, Wilson CB, Gottshalk GW. Pathophysiology of experimental glomerulonephritis in rats. $\mathcal{F}$ Clin Invest $1974 ; 53: 1402-23$.

6 Hostetter TH, Olsen JL, Rennke HG, Venkatachalam MA, Brenner BM Hyperfiltration in remnant nephrons: a potentially adverse response to renal ablation. Am 7 Physiol 1981;241:F85-93.
7 Hostetter TH, Troy JL, Brenner BM. Glomerular haemodynamics in experi-

8 Lubowitz H, Purkerson ML, Sugita M, Bricker NS. GFR per nephron and per kidney in chronically diseased (pyelonephritic) kidney of the rat. Am $\mathcal{F}$ Physiol $1969 ; 217: 853-7$

9 Blantz RC, Wilson CB. Acute effects of antiglomerular basement membrane antibody on the process of glomerular filtration in the rat. $\mathcal{F}$ Clin Invest 1976; 58:899-911.

10 Kleinknecht C, Saluski I, Broyer M, Gubler MC. Effect of various protein diets on growth, renal function and survival of uraemic rats. Kidney Int 1979;15:

pras AM, Paraskevakou H, Zoob S, Evans DJ, Rees AJ. Effect of dietary tomy in rats. Clin Sci 1983;65:399-406.

12 Giordano C. Protein restriction in chronic renal failure. Kidney Int 1982;22: 401-8.

13 Maschio G, Oldrizzi L, Tessitore N, et al. Effects of dietary protein and phosphorus restriction on the progression of early renal failure. Kidney Int 1982;22: $371-6$

14 Kopple JD, Roberts CE, Grodstein GP, et al. Low protein diets and the non dialyzed uraemic patients. In: Avram MM, ed. Prevention of kidney disease and long term survival. London: Plenum Medical, 1982:3-22.

15 Oksa H, Pasternack A, Luomala M, Sirvio M. Progression of chronic renal failure. Nephron $1983 ; 35 \cdot 31-4$.

16 Chantler C, Garnett ES, Parsons V, Veall N. Glomerular filtration rate measurement in marnett ES, Parsons ment in man by the single method using 51 -Cr-ED TA. Clin Sci 1969;37:169-80. plasma flow with sodium iodohippurate I-131. FAMA 1964;187:811-3.

18 Brunner FP, Brynger $\mathrm{H}$, Chantler $\mathrm{C}$, et al. Combined report on regular dialysis and transplantation in Europe IX, 1978. Proc Eur Dial Transplant Assoc 1979; 16:2-73.

19 Rocha A, Marcondes M, Malnic G. Micropuncture study in rats with experimental glomerulonephritis. Kidney Int 1973;3:14-23.

20 Blantz RC, Tucker BJ, Gushwa CC, et al. Glomerular immune injury in the rat: the influence of angiotensin II and $\alpha$-adrenergic inhibitors. Kidney Int 1981; 20:452-6

21 Lianos EA. Biosynthesis and role of arachidonic acid metabolites in glomerulo-

2 Azar S, Johnson MA, Tobian L. Single nephron dynamics in the Kyoto hyperrat. Fed Proc 1976;35:556.

ank N, Alterman L, Aynedjian HS. Selective deep nephron hyperfiltration in unineph

24 Cotran RS. Glomerulosclerosis in reflux nephropathy. Kidney Int 1982;21:528-34. 25 Arze RS, Ramos JM, Owen JP, et al. The natural history of chronic pyelonephritis in the adult. Q F Med 1982;204:396-410.

, Black DAK, Jones NF, eds. Renal disease. Oxford: Blackwell Scientific, 1979:329-45.

27 Davies DJ, Brewer DB, Hardwicke J. Urinary proteins and glomerular morphometry in protein overload proteinuria. Lab Invest 1978;38:232-43.

(Accepted 29 August 1984)

\title{
Regional variations in British alcohol morbidity rates: a myth uncovered? I: Clinical surveys
}

\author{
RICHARD W LATCHAM， NORMAN KREITMAN， MARTIN A PLANT, ALEX CRAWFORD
}

\begin{abstract}
Officially recorded rates of many alcohol related problems are much higher in the north than in the south of Britain. To try to shed some light on this the pattern and threshold for use of psychiatric and medical hospital services for alcohol dependence, abuse, and psychosis were studied in three areas differing greatly in official rates of alcohol related problems-namely, the Highland and Tayside regions in Scotland and part of the South East Thames region in England. The disparity in psychiatric admissions for alcohol dependence, abuse, and psychosis
\end{abstract}

University Department of Psychiatry, Royal Edinburgh Hospital, Edinburgh EH10 5HF

RICHARD W LATCHAM, MB, MRCPSYCH, research psychiatrist, MRC unit for epidemiological studies in psychiatry

NORMAN KREITMAN, FRCP, FRCPSYCH, director, MRC unit for epidemiological studies in psychiatry

MARTIN A PLANT, BSC, PHD, senior research fellow, alcohol research group

ALEX CRAWFORD, BA, MSC, research fellow, alcohol research group

Correspondence to: Dr R W Latcham. were found to be largely explained by admission policies which reflected geographical factors.

The results of this study did not support the conventional view that rates of treated morbidity due to alcohol are appreciably higher in the north.

\section{Introduction}

Officially recorded rates of many alcohol related problems are substantially higher in the north of Britain than they are in the south. ${ }^{1-4}$ The rate of first admissions to psychiatric hospitals for alcohol dependence, abuse, and psychosis is 12 times higher in the Highland region than it is in southern England. Information available about regional patterns of alcohol consumption has been very limited and is conflicting. While some evidence indicates that there is a decreasing gradient in heavy drinking from the north west to the south east, ${ }^{56}$ other data suggest that community alcohol consumption levels in Scotland are almost indistinguishable from those south of the border. ${ }^{\text {? }}$

We present data from one of two separate yet complementary studies. Both were related to the Highland and Tayside regions in Scotland and part of the South East Thames region in England. These three areas were selected because of their differences in official rates of alcohol related problems. In 1981 
the rates for first admissions to psychiatric beds of residents in the three areas for alcohol dependence, abuse, and alcoholic psychosis (ICD (9th revision) codes 291, 303, 305.0) per 1000 population were: Highland 0.75 , Tayside 0.62 , Kent 0.06 (Scottish Home and Health Department and Department of Health and Social Security, personal communication, 1982). The first study was conducted to ascertain whether this difference, even if reflecting morbidity due to alcohol in each area, was affected by policy as reflected in threshold of severity of the conditions requiring admission or by differing provision of services, or both.

\section{Comparison of inpatients}

\section{METHOD}

Samples of inpatients whose primary diagnosis was alcohol dependence, abuse, or psychosis were interviewed during 1981-2. So far as possible the samples were consecutive. Because some patients stayed in hospital very briefly there was an equal bias in the three regions towards those who stayed longer. Demographic details of the samples were compared with available data on all eligible patients in each area, and it was found that the samples were representative in terms of marital state, age, source of referral, and, in Scotland, social class (social class data were not available in England).

The numbers of men and women patients interviewed in the three regions were: Highlands 90 and 20, Tayside 69 and 17, and Kent 31 and 10 respectively. These numbers reflected the rates of the diagnoses in the three areas. Over half of the interviews were carried out by one of us (RWL) and the remainder by male interviewers trained by RWL. These were charge nurses with clinical experience of alcohol dependence. Reliability among raters was tested. Each interviewer rated three interviews tape recorded by each of the other interviewers. Differences in ratings were limited to a question concerning amnesias, which was later discarded, and to small discrepancies in total alcohol consumption traceable to English interviewers' misinterpretation of Scottish slang (in other words, the original interviewer was correct). This high reliability among raters, already reported by Chick for that part of the interview concerned with dependence, ${ }^{8}$ reflected the highly structured nature of the interview, which lasted about one hour.

Data on alcohol consumption were collected relating to drinking during the previous week or, if this was atypical, the most recent typical week. This approach was used to avoid the bias associated with quantity-frequency methods noted by $J$ Duffy (paper presented at the alcohol epidemiology section (ICAA), Helsinki, 1982). Alcohol dependence was investigated using a schedule devised by Chick. ${ }^{8}$ This made operational the description by Edwards and Gross of the alcohol dependence syndrome. ${ }^{9}$ In addition, data were obtained concerning alcohol related consequences in the patient's family, work, and general health and related to public order. These items had been tested in other studies-for example, that of Kreitman et al on use and misuse of alcohol among brewers and directors (personal communication, 1984). They had been designed to elicit consequences occurring within the past two years. Particular attention was paid to the ascription of any consequences to alcohol. Biographical details were also obtained.

No patient refused to cooperate. Interviews were conducted simultaneously in the three areas.

\section{RESULTS}

There were no significant differences in the "typical" self reported alcohol consumption levels of respondents of the same sex among the three areas. Rates of alcohol related problems (health, family, public order, and employment) were also compared. Problem scores were derived by adding the number of problems each respondent attributed to his or her drinking in the past two years. Scores for severity of alcohol dependence were similarly derived by adding the number of symptoms of dependence experienced, but in the three months preceding hospital admission. The table gives the results. The only significant differences did not suggest that the patients in Kent were admitted at greater thresholds of severity or that those in the Highlands were admitted at lesser thresholds.

\section{Effects of provision and use of services}

Alternative methods of inpatient psychiatric treatment existed in each of the three areas and we therefore examined whether these alternatives were disproportionately developed or used.

\section{METHOD}

The alternative services considered were those for psychiatric outpatients and day patients. A centralised psychiatric case register in Tayside provided separate figures for first admissions, and for first

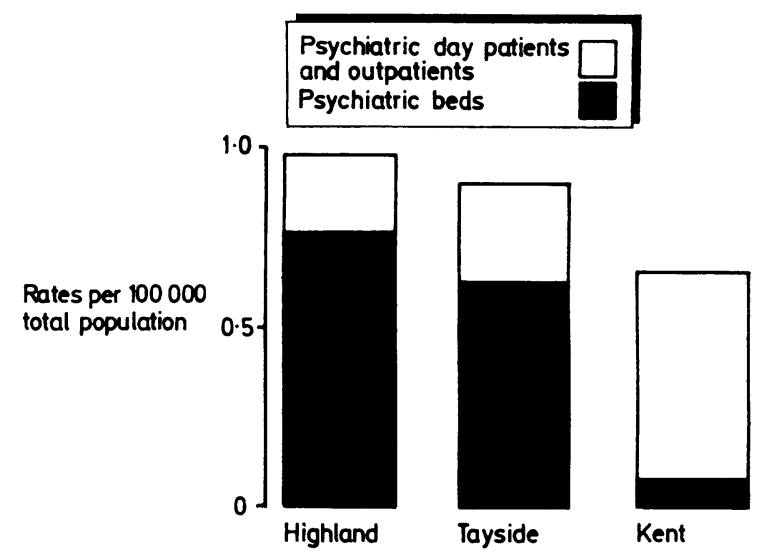

Use of psychiatric services in three areas for alcohol dependence and alcoholic psychosis during 1981 (data for men and women).

Patterns of alcohol consumption and alcohol related problems among patients admitted to psychiatric beds in three areas

\begin{tabular}{|c|c|c|c|c|c|c|}
\hline \multirow{2}{*}{ Variable } & \multirow{2}{*}{$\begin{array}{l}\text { Respondent's } \\
\text { sex }\end{array}$} & \multicolumn{3}{|c|}{ Area } & \multicolumn{2}{|c|}{ Level of significance* } \\
\hline & & Highland & Tayside & Kent & $\mathrm{F}$ & p \\
\hline Mean (SD) typical week's alcohol consumption (units) $\dagger$ & $\left\{\begin{array}{l}\text { Males } \\
\text { Females }\end{array}\right.$ & $\begin{array}{rr}180 & (102) \\
98 & (62)\end{array}$ & $\begin{array}{ll}192 & (134) \\
129 & (81)\end{array}$ & $\begin{array}{ll}183 & (135) \\
112 & (83)\end{array}$ & $\begin{array}{l}0.2 \\
0.8\end{array}$ & $\begin{array}{l}\text { NS } \\
\text { NS }\end{array}$ \\
\hline $\begin{array}{l}\text { Mean (SD) problem scores: } \\
\text { Health }\end{array}$ & $\left\{\begin{array}{l}\text { Males } \\
\text { Females }\end{array}\right.$ & 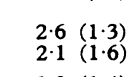 & $\begin{array}{l}3 \cdot 1(1 \cdot 6) \\
2 \cdot 8(1.6)\end{array}$ & $\begin{array}{ll}2 \cdot 1 & (1.5) \\
2 \cdot 6 & (1 \cdot 1)\end{array}$ & $\begin{array}{l}5 \cdot 0 \\
1 \cdot 1\end{array}$ & $\begin{array}{l}<0.01 \\
\text { NS }\end{array}$ \\
\hline Family & $\left\{\begin{array}{l}\text { Males } \\
\text { Females }\end{array}\right.$ & $\begin{array}{l}1 \cdot 8(1.4) \\
1 \cdot 2(1 \cdot 3)\end{array}$ & $\begin{array}{l}2 \cdot 2(1 \cdot 6) \\
1.9\end{array}$ & $\begin{array}{l}1.7(1.4) \\
1.5(1.5)\end{array}$ & $\begin{array}{l}1.6 \\
1.2\end{array}$ & NS \\
\hline Public order & $\left\{\begin{array}{l}\text { Males } \\
\text { Females }\end{array}\right.$ & $\begin{array}{l}1.2(1.2) \\
0.4(0.9)\end{array}$ & $\begin{array}{l}1 \cdot 7(1.3) \\
0.6(1.0)\end{array}$ & $\begin{array}{l}0.9(1.3) \\
0.6(0.7)\end{array}$ & $\begin{array}{l}5 \cdot 6 \\
0.4\end{array}$ & ¿ \\
\hline Employment & $\left\{\begin{array}{l}\text { Males } \\
\text { Females }\end{array}\right.$ & $\begin{array}{l}1 \cdot 7(1 \cdot 4) \\
1 \cdot 4\end{array}$ & $\begin{array}{l}1 \cdot 9(1 \cdot 5) \\
1 \cdot 4 \\
(1 \cdot 3)\end{array}$ & $\begin{array}{ll}1 \cdot 1 & (1 \cdot 2) \\
1 \cdot 0 & (1 \cdot 1)\end{array}$ & $\begin{array}{l}4 \cdot 3 \\
0 \cdot 4\end{array}$ & $\begin{array}{l}-0.05 \\
\text { NS }\end{array}$ \\
\hline Mean (SD) severity of alcohol dependence score & $\left\{\begin{array}{l}\text { Males } \\
\text { Females }\end{array}\right.$ & $\begin{array}{ll}29 & (10) \\
22 & (7)\end{array}$ & $\begin{array}{ll}29 & (12) \\
30 & (10)\end{array}$ & $\begin{array}{ll}23 & (14) \\
26 & (12)\end{array}$ & $\begin{array}{l}2 \cdot 6 \\
3.5\end{array}$ & $\underset{<0.05}{\text { NS }}$ \\
\hline
\end{tabular}

NS = Not significant.

* One way analysis of variance for each sex, with $F(2,187)$ for men and $F(2,44)$ for women.

One way analysis of variance for each sex, with $\mathrm{F}(2,187)$ for men and $\mathrm{F}(2,44)$ for women.
$\dagger$ Each 
contacts with the register who were not also admitted, for alcohol related diagnoses in 1981 .

In the Highlands and Kent all letters of reply to referring agents were read by RWL if a patient was a new referral in 1981. Those who were not admitted were counted as outpatient cases if alcohol was mentioned as a major contributory factor in their psychiatric presentation. In Kent numbers of first attenders at a day unit were easily and reliably obtained (to the exclusion of those admitted) from records held on computer. All patients admitted or seen as day patients for alcohol related diagnoses routinely complete the severity of alcohol dependence questionnaire. ${ }^{10}$ There were no day patients in the Highlands.

\section{RESULTS}

The figure shows the results. When psychiatric inpatient, outpatient, and day patient rates were added the total rates of morbidity due to alcohol treated by psychiatric services approximated. The ratio between rates in the Highlands and Kent was only $1.53: 1$, compared with 12.5:1 for psychiatric inpatient rates. A comparison of day patients and inpatients in Kent who completed the alcohol dependence questionnaire showed no significant differences.

\section{Conclusions}

These findings do not support the conventional view that there is a large north to south gradient in rates of treated morbidity due to alcohol. Patterns of alcohol consumption in the general population are reported in our accompanying paper. ${ }^{11}$

This study was funded by the Medical Research Council and by the Economic and Social Research Council. Additional support was provided by the Scotch Whisky Association and by the Brewers' Society. Some of the data will be included in a Birmingham University MD thesis.

\section{References}

1 Plant MA, Pirie F. Self-reported alcohol consumption and alcohol-related

problems: a study in four Scottish towns. Soc Psychiatry 1979;14:65-73.
2 Kilich S, Plant MA. Regional variations in levels of alcohol-related problems in Britain. Br f Addict 1981;76:47-62. (Erratum 1982;77:211.)

3 Davies PT. The pattern of problems. In: Plant MA, ed. Drinking and problem drinking. London: Junction, 1982:111-34.

4 Haskey JC, Balarajan R, Donnan SPB. Regional variations in alcohol-related problems within the United Kingdom. Community Med $1983 ; 5: 208-19$.
Office of Population Censuses and Surveys Geral household survey ffice of Population Censuses and Surveys. General household survey 1978. London: HMSO, 1980

6 Cummins RO, Shaper AG, Walker M, Wale CJ. Smoking and drinking by middle-aged British men : effects of social class and town of residence. Br Med $\mathcal{F}$ middle-283:1497-502.

7 Wilson SP. Drinking habits in the United Kingdom. Population Trends 1980; No 22, winter: 14-8.

8 Chick J. Alcohol dependence: methodological issues in its measurement: reliability of the criteria. $B r \mathcal{F}$ Addict $1980 ; 79: 175-86$

9 Edwards G, Gross M. Alcohol dependence: provisional description of a clinical syndrome. $\mathrm{Br}$ Med $\mathcal{f} 1976 ; \mathrm{i}: 1058-6$

10 Stockwell T, Hodgson R, Edwards G, Taylor C, Rankin H. The development of a questionnaire to measure severity of alcohol dependence. $\mathrm{Br} \mathcal{J}$ Addict $1979 ; 73: 79-87$

11 Crawford A, Plant MA, Kreitman N, Latcham RW. Regional variations in British alcohol morbidity rates: a myth uncovered? II : Population surveys.
$B r$ Med $\mathcal{f} 1984 ; 289: 1343-5$.

(Accepted 31 August 1984)

\title{
Regional variations in British alcohol morbidity rates: a myth uncovered? II: population surveys
}

\author{
ALEX CRAWFORD， MARTIN A PLANT， NORMAN KREITMAN， RICHARD W LATCHAM
}

\begin{abstract}
Regional variations in officially recorded rates of alcohol related morbidity in Britain were investigated by surveying community drinking habits of a randomly selected sample of adults in the Highlands, Tayside, and part of the South East Thames region. Contrary to expectations, patterns of alcohol consumption did not differ in a manner consistent with the much higher rates of alcohol related problems recorded in the north.
\end{abstract}

\section{Introduction}

In our accompanying paper we reported that officially recorded levels of alcohol related problems are much higher in the north of Britain than they are in the south. ${ }^{1}$ Paradoxically, evidence

\footnotetext{
University Department of Psychiatry, Royal Edinburgh Hospital, Edinburgh EH10 5HF

ALEX CRAWFORD, BA, MSC, research fellow, alcohol research group

MARTIN A PLANT, BSC, PHD, senior research fellow, alcohol research group

NORMAN KREITMAN, FRCP, FRCPSYCH, director, MRC unit for epidemiological studies in psychiatry

RICHARD W LATCHAM, MB, MRCPSYCH, research psychiatrist, MRC unit for epidemiological studies in psychiatry

Correspondence to: Mr A Crawford.
}

about the corresponding levels of alcohol consumption in different regions is both restricted and inconsistent. In order to clarify the position two surveys were conducted. Both of these related to the Highlands, Tayside, and south east Kent. The first survey is described in our accompanying paper and was concerned with clinically diagnosed problem drinkers. This paper reports the results of the second survey, which was concerned with patterns of alcohol consumption in the general population.

\section{Method}

Data were obtained by interviewing samples of people drawn from the electoral register in each of the three areas. The initial sampling pool comprised 40 electors from 40 polling districts in each area. The polling districts were randomly selected within each area by (a) ranking parliamentary wards by size of population (largest to smallest); (b) similarly ranking polling districts (or civil parishes in rural areas) within wards; (c) dividing the cumulative total of electors $(\mathrm{N})$ by 40 ; and $(d)$ randomly selecting a number (which corresponded to an elector) between one and N/40. The polling district within which that elector resided became the starting point for selecting the remaining 39 districts. This was achieved by adding (N/40) 39 times to that initial random number.

Forty respondents aged 18 and over on 1 September 1982 were randomly selected from each polling district by choosing every 10 th elector after a randomly chosen starting number between one and $M-450 . M$ was the number of electors in the polling district. This procedure randomly produced 1600 names equally divided by sex in each of the three survey areas. In order to increase the chance 